\title{
Reflecting on Peter and the Wolf: Fantasy or Prophecy
}

\author{
Alexander Rosenblatt \\ Zefat Academic College, Zefat, Israel
}

\begin{abstract}
The article discusses the socio-cultural aspect of the popular musical tale Peter and the Wolf by Sergei Prokofiev (1891-1953). The discussion takes into account the circumstances of composer's life at time of writing the piece, as well as the political and ideological context of Soviet Russia of the 1930s. The main discussion is connected with the campaign of the Soviet authorities against formalism in musical art, which led to a ban on the staging of many works for the musical theater, including Prokofiev's Romeo and Juliet commissioned by the Kirov (Mariinsky) Theater in Leningrad just a year before the ban. The circumstances surrounding the arrest of Prokofiev's first wife are part of the discussion, along with an explanation of what "pioneer Peter" means. The author claims that, conceived as a children's fairy tale, the work has an ambiguous ending, which can be viewed as a kind of prophecy expressed in Aesopian language.
\end{abstract}

Keywords: Prokofiev, Peter and the Wolf, Soviet composer, Stalinist ideology, anti-formalism campaign

\section{Introduction}

Pum, pum, purum-pum-pum.... The carefree rising melody of the violins, familiar from childhood to nearly three generations of children in the Western Hemisphere is unmistakably recognized as the opening theme of Prokofiev's Peter and the Wolf, a musical tale that aims to acquaint children with the musical instruments of the orchestra, as described in any source referring to this work. Indeed, each animal is represented by different instrument, which plays its melody every time when a narrator mentions its emergence in the story line.

Remember the last words of the fairy tale, when a narrator calls us to imagine the triumphant procession led by Peter. "And if one would listen very carefully, he would hear the duck quacking inside the wolf, because the wolf, in his hurry, had swallowed her alive". There is not a single child who would be complete with this end and would not ask parents a question of how to pull out a duck without killing a wolf. The author was among such children, and even till now, he asks himself this question. Recently, however, the author's question to himself has slightly changed: What is the meaning of this ending, namely what Prokofiev tried to tell us (or rather himself) by inventing this symbol? Reflection on this question prompted the author to ask himself a number of other questions: When was the fairy tale written? What happened in the life of the composer during that period? Where did he live? Was he afraid of something? The pages below are an attempt to shed light on these and other related issues.

\footnotetext{
Alexander Rosenblatt, Ph.D., lecturer, Department of Literature, Art, and Music, Zefat Academic College, Zefat, Israel.

1 Hereinafter, the English lyrics of a fairy tale are in accordance with: https://genius.com/Sergei-prokofiev-peter-and-thewolf-op-67-lyrics.
} 


\section{Pioneer Peter}

The very beginning of the fairy tale introduces us its hero: "Early one morning, Peter opened the gate and went out into the big green meadow". Original Russian text, however, includes one more word related to Peter: “Рано утром пионер Петя открыл калитку и вышел на большую зеленую лужайку"² (Early one morning, pioneer Peter opened the gate and went out into the big green meadow). What does this word mean and why is it not used in the English version of the text?

Most of the sources refer to the word pioneer in the context of Soviet socio-cultural realities of the 1930s as to a kid/teen between 9 and 14 who is a member of All-Union Lenin Pioneer Organization. Some sources use collocation "young pioneer" (юный пионер in Russian) in order to fit into the two categories - ages range and organizational belonging. All-Union Lenin Pioneer Organization (Всесоюзная пионерская организация имени В.И. Ленина) was a children's union established in 1922 that lasted until 1991. The organization was similar to the scouts in the Western world, i.e., organization that equips teens with social and survival skills. The pioneers were also equipped with strong ideological skills and therefore were considered the "good guys" of Soviet youth. The image of the young pioneer was one of the noteworthy figures in Soviet literature, art, and music in the 1930s onwards. In addition, radio program Pioneer dawn (Пионерская зорька) and All-Union Young Pioneer camp Artek (both established in 1925) were signs of the attention that the Soviet government paid to raising children in a communist spirit.

The association of the hero of a musical fairy tale with a pioneer organization is in itself a remarkable detail, given that it was created by a Russian composer who had arrived in a Soviet country just a few months before. According to Vishnevetsky (2011), the way of Soviet man thinking remained alien to Prokofiev-he finally returned to the country in the summer of 1936, when he managed to get an apartment in Moscow, and was far from agreeing with everything that was happening around. Moreover, Prokofiev arrived in the USSR ${ }^{3}$ with his wife, Spanish singer Carolina Codina, and their two sons, Sviatoslav and Oleg, none of whom was born Soviet or even Russian.

\section{The Way Home}

Born in 1891, in Sontsovka (present-day Ukraine), Sergei ${ }^{4}$ Prokofiev graduated from St. Petersburg Conservatory as a composer (1909) and a pianist (1914). In May 1918, Prokofiev left Russia, moving first to the United States and then to France. During the 1920s, Prokofiev's name became familiar in the West. However, as a pianist, he was inferior in glory to Rachmaninov, and as a composer - to Stravinsky. Although Parisian music critics wrote in the early 1930s that Prokofiev was "practically a citizen" in the French capital, it "practically" meant that official recognition with all the ensuing consequences did not occur. "He was only semi-successful in the West", says pianist Vladimir Ashkenazy.

He didn't attain the degree of fame that would satisfy his ambitions. In the West, he tried to be even more avant-garde than he was naturally, and it didn't work. He was going along with the tastes of fashion, but it was against his nature. (Cited in Norris, 2003)

\footnotetext{
2 According to С. Прокофьев. Петя и волк. Симфоническая сказка для детей. Санкт-Петербург: Композитор, 2005.

3 That is, the (former) Soviet Union or, officially, Union of Soviet Socialist Republics.

${ }^{4}$ In most sources, the name of Prokofiev is spelled as Sergei, and in some-Sergey or Serge. The author uses the most accepted spelling, offering other options only for direct quotes in which they are used. This is same for Sviatoslav Prokofiev, who is spelled as Svyatoslav only in few direct quotes.
} 
In 1927, for the first time after his departure, Prokofiev arrived with a nearly two-month concert tour in the USSR, where he was warmly welcomed. In subsequent years, he arrived in the USSR two more times. The impression was that no one reproached the composer for his long absence at home; moreover, they were waiting for him back. They waited not empty-handed: order for the ballet "Romeo and Juliet" followed from the Kirov Theater, supported by a clear hint of who they want to see as the leading Soviet composer. Returning home was without preconditions and, furthermore, with the provision of apartment in the center of Moscow. And Prokofiev made up his mind. Sviatoslav Prokofiev, composer's son, explains the situation: 'It's important to know", he says, "that Prokofiev was very Russian. He loved Russia. He had lots of happy memories of his youth there" (Norris, 2003).

"I remember how on the eve of the family's relocation to Moscow, he [father] explained to me why our family changes the capitalist country for the USSR: All the people work there, everything is built on justice..." (Sandler, 2016) ${ }^{5}$.

"In the Thirties," says Sviatoslav, "there were many people among the intelligentsia who were in favour of communism, because, in theory, it was a very just system, but the practicalities hadn't been considered" (Norris, 2003).

Serge Prokofiev Jr., grandson of the composer, offers his own vision about his grandfather's long stay in the West and his return to Soviet Russia in the 1930s:

\footnotetext{
Many sources claim that the grandfather emigrated from Russia in 1918. But this is not true! He went to see the world, dreamed of since his childhood, "breathe fresh air", find out how things are going in music and theater abroad, show himself and then return, as he explained to Lunacharsky [the first Commissar of Education in the Soviet government-A.R.] the purpose of his trip. He actually completed the previously scheduled circle, and his return home was absolutely logical. Another question is that the time for this was inappropriate. (Sandler, 2016)
}

Be that as it may, one day, the composer, his wife, and their two sons arrived in Moscow with Soviet passports, issued and re-issued, in order to occupy a beautiful four-room apartment on the Garden Ring given to the family of he who becomes the main Soviet composer. Moreover, the Soviet authorities, as an exception, allowed him to bring a luxurious blue Ford, acquired shortly before his arrival by a man who loved beautiful things and...not only things. Here, we have to make a digression.

\section{The First Muse}

Carolina (Lina) Codina was born in Madrid in 1897 into a family of opera singers - tenor Juan Codina and soprano Olga Nemysskaya. She met Sergei Prokofiev in New York in 1918, when she first saw him at Carnegie Hall, at the premiere of his First Piano Concerto. In her youth, Lina Codina was a dazzling beauty. In addition to Spanish and English, she spoke three more languages, including Russian. Being a professional singer, she performed under the stage name Carolina Llubera (the family name of her grandmother). Lina became the prototype of Princess Lynette from Prokofiev's opera Love for Three Oranges. She performed several new works by Prokofiev in America and Europe, including his musical tale The Ugly Duckling (Golitsyna, 2013). Critical reviews of her singing were controversial and ambiguous. Nevertheless, some of her performances were very successful, especially on radio. One of the most vibrant was her appearance in the Milan Opera immediately after her marriage, where she sang the role of Gilda in Verdi's opera Rigoletto with great success. There were

\footnotetext{
${ }^{5}$ Hereinafter, all direct quotes from sources in Russian are translated by the author.
} 
other operatic roles. In the Soviet Union, she had several appearances on Radio Comintern. But in general, her musical career did not work out.

Five years after Lina's fateful visit to New York's Carnegie Hall, the most romantic period in her life ended: Sergei and Lina got married (see Figure 1). Golitsyna (2013) refers to Simon Morrison's opinion that their marriage has never been happy. Lina married Prokofiev, being pregnant. Prokofiev cannot be called a good family man. He did not want to marry and repeatedly told Lina that she could not count on marriage. However, Lina enjoyed being his companion and accompanying him on tours and social events. Before the marriage, their relationship was very uneven; she repeatedly left him, returned again, he left her and lived with her again. Predota (2016) describes the relationship of a couple, bringing the following details:

The period of initial courtship and romance was predictably pure bliss. Romantic attachment aside, the couple traveled together and formed a successful professional union. They gave a number of performances, premiering among others his Five Songs Op. 36 dedicated to Lina, and they managed to attend every cocktail party and social gathering within a 100-mile radius. Yet, love tends to ignore important warning signs. She complained of his rudeness and he promised to improve. When she cancelled a date, he told her "he could always find someone else." Crisscrossing Europe, Lina kept up her stage ambition, but after four years without a marriage proposal, she threatened to walk out on him. Apparently he told her to go ahead, yet as fate will have it, she became pregnant. The couple married in October 1923 in Ettal, Germany. For Prokofiev, who thoroughly enjoyed his life as a cosmopolitan artist—-forming romantic attachments in different countries during his tours — married life was simply not agreeable.

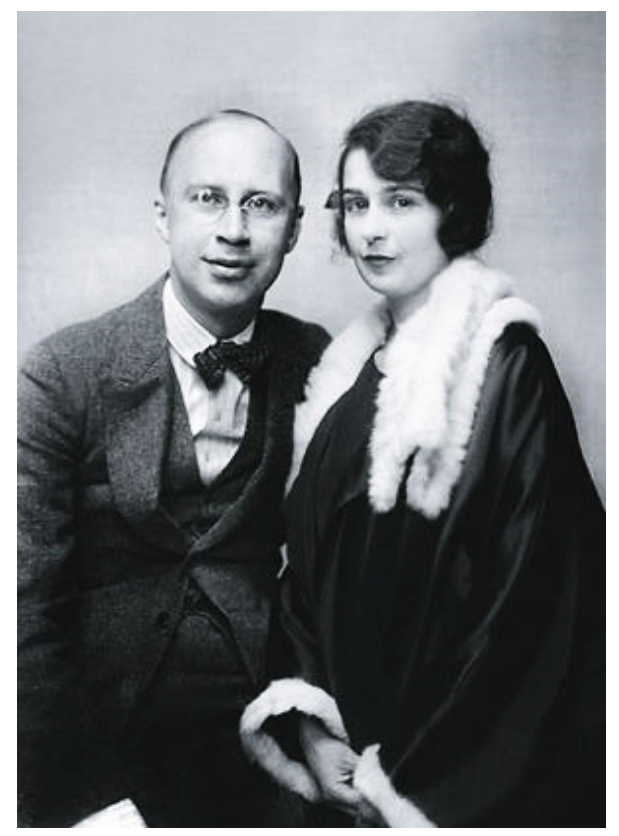

Figure 1. Sergei and Lina Prokofiev, c. 1925.

In 1928, Lina became pregnant again. The couple lived in Paris for 12 years, and their marriage was preserved mainly because they rarely saw each other and often lived in parallel lives. In the Soviet Union, however, they settled in the same apartment and were forced to endure each other, at least for a while.

\section{A Happy Ending to the Classic Tragedy}

In 1935, Prokofiev in collaboration with theater producer Sergei Radlov and playwright Adrian Piotrovsky completed work on the ballet Romeo and Juliet, and the management of the Kirov Theater approved music for it. 
However, the end of the play was different from the Shakespearean: In the ballet finale, the heroes not only survived, but also retained their romantic relationship. Such an attempt on the classic plot caused bewilderment among the censors. The authors rewrote the script, but staging was still banned, presumably due to "non-ballet" music $^{6}$.

1936 in the USSR began with the large-scale anti-formalism campaign, which clearly meant the attempt of the Stalinist ideology on the creative activity of writers, composers, and theatrical figures. The Pravda newspaper published critical articles on two works by Dmitry Shostakovich — the opera Lady Macbeth of Mtsensk and the ballet The Limpid Stream. One of the publications was called "Muddle instead of Music", and the second one was "The False Ballet". After such devastating reviews by the official press, the management of the Kirov Theater could not risk it. The premiere of the ballet could cause not just discontent on the part of the authorities, but real persecution. The situation was complicated by the fact that one of the authors of the libretto of Prokofiev's ballet, Adrian Piotrovsky, was convicted and executed in 1937. His name was removed from all documents, and choreographer Leonid Lavrovsky became one of the co-authors.

The premiere of the ballet took place in Brno, Czech Republic, three years after it was written. In the USSR, the stage production of "Romeo and Juliet" would be allowed only in 1940. Serious passions flared up around the ballet. The innovative "non-ballet" music of Prokofiev provoked real resistance from artists and musicians. The former could not get used to the new rhythm, and the latter were so afraid of failure that they even refused to play at the premiere- two weeks before the performance. Lavrovsky asked Prokofiev to change the score. After discussions, the composer finally added several new dances and dramatic episodes. The new ballet was significantly different from the one that was staged in Brno. The original version of the ballet - with a happy ending - was recovered in 2008. As a result of research by Professor Simon Morrison of Princeton University, the original libretto was made public. The play on it was staged by choreographer Mark Morris for the Bard College Music Festival in New York ${ }^{7}$.

\section{In a Trap}

In the early 1936, after attending with his own kids, a couple of performances at the Moscow Children's Musical Theater, Prokofiev was invited to write something for this theater.

"In the spring of 1936", he recorded in his diary,

I started a symphonic tale for children titled "Peter and the Wolf," Op. 67, to a text of my own. [Prokofiev had first rejected a text prepared by a poet recommended by the theater director, on the grounds that it was clichéd.] Every character in the story had its own motif played each time by the same instrument. (Cited in Smith, 2008)

Although this particular narrative is not entirely cheery, since the wolf's swallowing of an unfortunate duck comes to mind, the sonic side of things is so inventive and engaging that the whole thing seems somehow thoroughly uplifting (Smith, 2008).

"If the story has a moral", says Robinson (1987, p. 322), "it seems to be this: don't be afraid to challenge established beliefs...or to take risks". The premiere took place on May 2, 1936, and the work quickly gained wide popularity, especially after it was released as sound recordings, later adapted for ballet and finally turned

\footnotetext{
${ }^{6}$ According to: "Ballet 'Romeo and Juliet' by Sergei Prokofiev. Big Drama and Happy Ending" (in Russian). Kultura.RF (portal, supervised by the Ministry of Culture of the Russian Federation). Editorial. Retrieved April 24, 2019 from https://www.culture.ru/ materials/163654/balet-romeo-i-dzhuletta-sergeya-prokofeva-bolshaya-drama-i-schastlivyi-final. ${ }^{7}$ Ibid.
} 
into eponymous animated film by Walt Disney to whom the composer gave a copy of an unreleased score during his last concert trip to the United States in 1938.

Despite the terrible time and political problems arising from Stalinist criticism, it was relatively easy for Prokofiev to adapt to his native culture, which he knew well,

but Lina found it impossible to adjust. Living in Moscow at the start of the Great Terror was no easy task. [...] Neighbors were dragged from their beds by secret police in the middle of the night, and Lina was seriously alarmed. (Predota, 2016)

The atmosphere in which they lived was very unrest. Prokofiev should have understood that he was trapped. American musicologist Richard Taruskin, who studied at Moscow Sate Conservatory as cultural exchange student in the early 1970s, describes the situation on an example of a musicologist who was first oppressed and then was among the oppressors for others:

"So Livanova was a bitaya!" exclaimed a friend to whom I had sent a draft of this essay for comment. Bitaya, the feminine past participle of the verb "to beat," used here as a substantive, means "one beaten down." According to the Leninist principle of kto kogo ("who [will do it] to whom," originally intended to encapsulate the inescapable class struggle, but colloquially something closer to "dog eat dog"), those beaten today will become tomorrow's beaters; and that certainly applied to the dreaded Livanova. (Taruskin, 2019, p. 13)

Lina demanded that her husband take some steps to return to the West. In the end, Prokofiev had a connection with a young woman who devoted herself entirely to him, helped in his work, becoming something of his secretary and housekeeper. She did not demand anything from him, did not reproach anything, and in her company Prokofiev felt more comfortable and calmer.

\section{The Second Muse}

When she met Prokofiev in 1938 in a sanatorium in Kislovodsk, a student at the Literary Institute, Mira Mendelssohn was 23 years old, he was 47. Her father, Professor Abram Mendelssohn, was a well-known economist who worked at Gosplan. Three years after meeting Mira, Prokofiev left his family, not without hesitation, taking with him only a small suitcase. In three months, in June 1941, Nazi's Army invaded the USSR territory, and the Great Patriotic War (part of the WWII, 1941-1945) began. The blue Ford, with which Prokofiev returned to the USSR, was requisitioned at the beginning of the war, as was all the personal transport of the country's population (Klyuchnikova, 2019).

Many people, including creative intelligentsia and, especially, peoples of Jewish origin, moved from the occupied cities and cities at risk of occupation, including Moscow and Leningrad, to the East of the country. Prokofiev had no other occupation except for his activity as a composer, and Mira was a Jewish. So, the question of evacuation arose directly. Prokofiev should have proposed Lina to join him (them) with the children.

Despite Sergei's persuasion, Lina refused to go to the evacuation together, staying with her sons in Moscow. Sergei was traveling gloomily, he was tormented by his own fault, and Mira... Those who sat in the train with their acquaintances, many of whom were friends with the Prokofievs for many years, did not know what to call her. Hiding the embarrassment under the joke, they named her "friend of genius". And Mira diligently smiled in response, pretended that she does not expect more (Varyash, 2013).

Immediately after returning to Moscow, Mira began increasingly demanding Sergei's divorce from Lina. Life was returning to the old peaceful rut, and everything that was overlooked during the war began to matter 
and weight again. Staying further in the rank of "friend of genius" seemed indecent to Mira. In early 1945, her father helped them in getting an apartment on the outskirts of Moscow. A week later, Prokofiev, who came out to a nearby pastry shop, fell on a slippery street and hit his head hard. The recovery took months and was not full.

In 1946, the Prokofievs bought a cottage and a plot on Nikolina Gora, a holiday village near Moscow (see Figure 2). Former owners asked for 300,000 rubles - a huge amount. Prokofiev had just received the Stalin Prize, but this was not enough, and he had to take a big loan. However, the old dream of his own house finally came true. In 1947, Sergey and Mira moved to the apartment of Mira's parents in the center of Moscow, where Prokofiev lived the last six years of his life, leaving for Nikolina Gora in the summer. Beginning in 1945, Sergei started negotiations with Lina for a divorce. She refused every time: First, never being a true Catholic, she persistently referred to the sanctity of the wedding, and then she stated that she would not divorce until Sergei received permission for her to return to France. Then, she began to contact herself with representatives of foreign embassies, which ordinary Soviet citizens preferred to bypass. Sons told Sergei that they had to leave everything as it was.

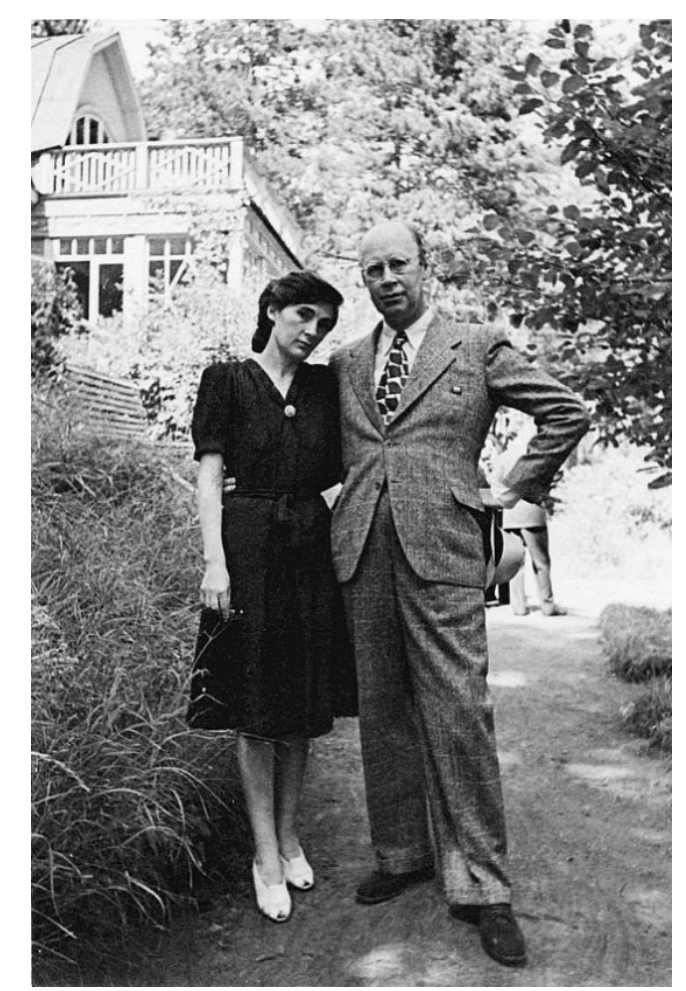

Figure 2. Prokofiev and Mira, Nikolina Gora, 1946.

And then the incredible happened. The official called the composer saying that there was no need for a divorce: A 24-year marriage with Lina, contracted, firstly, abroad, and secondly, according to church rites, according to Soviet laws, simply...does not exist ${ }^{8}$.

\footnotetext{
${ }^{8}$ Various sources (cf. Golitsyna, 2013, Varyash, 2013, and Sandler, 2016) offer different versions of this passage: Prokofiev's appeal to court for a divorce or just a phone call by an official, but this does not change the point: Prokofiev received a divorce without the consent of his wife.
} 


\section{The Fulfilled Prophecy}

Immediately after the war-in 1946-1947—a situation arose when the former foreigners had some hope of returning to the West. Lina's housemate, who was French, was able to get permission to leave with the help of the French embassy. This made Lina start active actions. She really wanted to return to France, wanted to see a mother who was very old, sick, and felt very lonely in Paris. Lina wrote numerous letters to the Soviet authorities with a request to allow her to see her mother. It was all to no avail. At that time, she very intensively attended receptions at foreign embassies - American, French, British, and even Japanese - hoping to get help in leaving the USSR. After her arrest, she was accused of trying to flee the country and stealing secret documentation. The fact is that during the war, Lina Prokofiev worked at the Soviet Information Bureau as a translator and broadcaster on foreign broadcasting. She was also accused of being connected with people declared "enemies of the people", and that she illegally handed over letters through the French embassy to relatives and friends in France. At that time, all this considered foreign espionage.

The 1948 ruling on "formalism" in music and the subsequent arrest of his first wife Lina broke Prokofiev: In the end, the composer returned to the USSR voluntarily, in times that were not the best for the country. It was for Prokofiev, who trusted his native country, an unbearable blow to deserve the label of an anti-people and non-patriotic composer and realize that you are personally responsible for imprisoning your children's mother. Life, creativity were deprived of meaning.

\section{The 1948 Campaign}

1948 was marked by a second anti-formalism campaign. The Stalinist ideology, which had suspended control over the already patriotic art of the time for the duration of the war, spread its wings. Prokofiev became the main target of the Communist party's decree on combating "anti-people formalism" in music. His works have ceased to perform ${ }^{9}$, the experimental opera The Story of a Real Man was removed from the staging-it would be staged only in 1960 (Erlichman, 2016). Although Prokofiev himself was not a Soviet man either before or after 1948 (as follows Vishnevetsky, 2011), he most likely was a supporter of the communist regime in the USSR and, being a direct and sincere man, at first took party criticism at face value.

The party criticism was aimed first of all at Prokofiev and Shostakovich, whose works

are especially clearly represented by formalistic perversions, anti-democratic tendencies in music, alien to the Soviet people and their artistic tastes. [...] The work of many pupils at conservatories is a blind imitation of the music of D. Shostakovich, S. Prokofiev and others ${ }^{10}$.

In support of this decree, a caricature depicting a line of little Shostakovichs leaving the conservatory building was posted in Sovetskaya Muzyka, the official journal of the Union of Soviet Composers (see Figure 3). In fact, it was rather the recognition of Shostakovich as the leading Soviet composer, at least since he remained in besieged Leningrad, composing the Seventh ("Leningrad") Symphony.

\footnotetext{
${ }^{9}$ Some sources, such as Editorial on Prokofiev at Soundtimes.Ru (https://soundtimes.ru/muzykalnaya-shkatulka/velikie-kompo zitory/sergej-prokofev), state that already in 1949, these restrictions were lifted by Stalin's personal order.

${ }_{10}$ Resolution of the Politburo of the Central Committee of the CPSU (b) "On the opera 'The Great Friendship' by V. Muradeli" (in Russian). Pravda, February 11, 1948. Reprinted in: Власть и художественная интеллигенция. Документы ЦК РКП(б)—ВКП(б), ВЧК-ОГПУ-НКВД о культурной политике. 1917-1953. Под ред. А.Н.Яковлева. Сост. А.Н.Артизов, О. В. Наумов. М.: Международный фонд “Демократия”, 1999 (Quotes: pp. 631-632).
} 


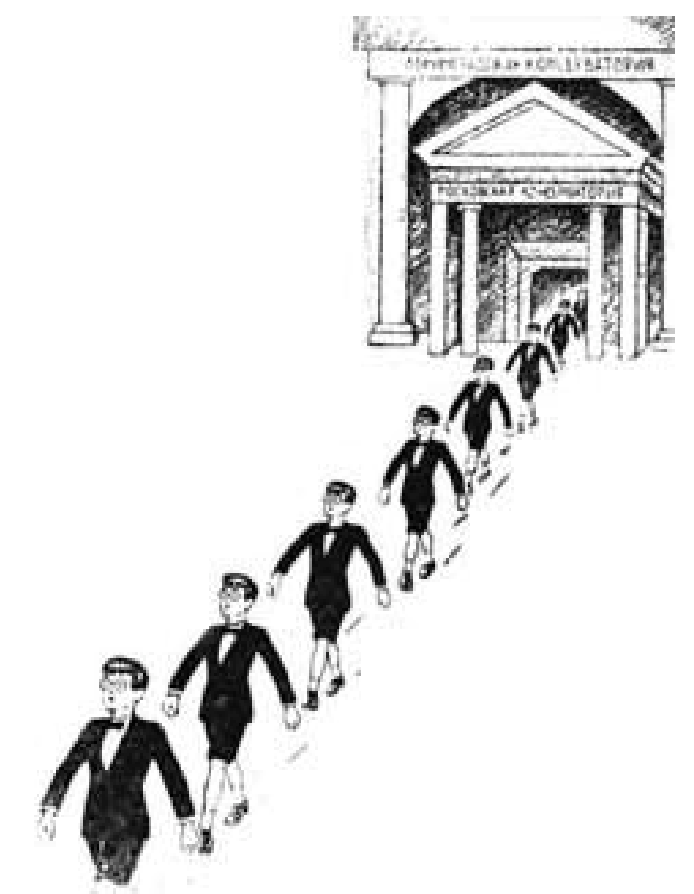

Figure 3. Caricature in Sovetskaya Muzyka 1948 No. 1.

Prokofiev's divorce with Lina largely served as a catalyst for her arrest. She was arrested a month after her marriage to Prokofiev was dissolved and her ex-husband married Mira Mendelson. But she did not know about it and in the camp she continued to consider herself the legitimate wife of Prokofiev.

\section{The Collapse}

"Svyatoslav and Oleg turned in vain to family friends for help", Morrison restores the chain of events.

They then trudged through the snow to Prokofiev's dacha outside of Moscow with the grim news. They had not seen their father for months. He listened in silence before stammering, enigmatically, "What have I done?" That evening, he and Mira searched his belongings to purge anything potentially incriminating from his cosmopolitan past. He burned foreign-language magazines, books, and letters at the kitchen stove. Lina would later assume that he too had been imprisoned. (Morrison, 2013, p. 7)

There is no doubt that Prokofiev's half-legal wedding, the pogrom inflicted on his music, and Lina's arrest are links in one chain. Lina Prokofiev's friends both in the West and in Russia accuse the great composer of indifference to the fate of the first wife and that he left the children to the mercy of fate. Simon Morrison (as follows Golitsyna, 2013) maintains that Prokofiev helped her financially when she was in the camp, but he did it not directly, but through the children, giving them money for food packages.

After the decree of the Central Committee in 1948, his position was very fragile due to criticism of the music of Prokofiev and Shostakovich. The author does not think that in such a situation he had any opportunity to ask for his ex-wife.

According to Sandler (2016), with reference to the opinion of Valentina Chembergi, who knew Lina Prokofiev well, it was impossible to help in this situation at all: "Molotov's wife sat in the camp, Kalinin's wife sat—even their husbands could do nothing". And this is despite the fact that Molotov and Kalinin were people of Stalin's close circle. 
And yet Prokofiev seemed to manage to remain happy even in such a situation, which was greatly facilitated by both the peculiarities of his character and Christian Science, a teaching with which Prokofiev met with in 1924 in Paris, after Lina joined it, and remained committed to it until the end of his days (Klyuchnikova, 2019). Christian Science also helped Lina to maintain the presence of mind during her stay in the camp (Sandler, 2016).

In July 1949, Prokofiev suffered a stroke. Doctors strictly forbade him to make music and especially to compose. Dreary years of illnesses and rare improvements, he sometimes managed to write something new.

The composer died on March 5, 1953, on the same day as Stalin. And they were buried on the same day, March 9. Prokofiev died in an apartment in the center of Moscow. On the day of the funeral, it was impossible to jostle through: Thousands of people came to the funeral of Stalin. Conductor Gennady Rozhdestvensky recalls:

There was a crowd of many thousands, and it was impossible to adjust the bus to the house. Then the composer's coffin was carried by six volunteer students. They walked two kilometers in five hours, sometimes dropping their sad burden onto the frozen sidewalk to rest. (Erlichman, 2016)

In May 1956, Lina Prokofiev was rehabilitated, a month later, she was released, and after eight of the 20 years, she was sentenced to. In April 1957, the Moscow City Court overturned a court decision of November 1947 on the illegality of the marriage of Lina and Sergei Prokofiev. At the same hearing, the court made a decision: Mira and Lina were declared legal widows of the composer.

Mira Mendelson died in June 1968 at the age of 54 and was buried next to Prokofiev. Lina managed to leave the USSR in 1974. She lived in Paris and died in 1989 at the age of 91 years.

\section{Conclusions}

For many people, Prokofiev's name is associated, first and foremost, with two of his works: the ballet Romeo and Juliet and the musical fairy tale Peter and the Wolf, both composed in the middle of the 1930s. The article discusses these works as the most fortunate Prokofiev's compositions with which he actually remains in history. If the only one work should be defined as the landmark, this would certainly be the fairy tale.

"If Sergei Prokofiev had composed nothing except Peter and the Wolf", says Smith, "he would have left a sizable mark. The work has helped introduce generations of children to the instruments of the orchestra and the concept of telling a story through music, fulfilling the goal Prokofiev set for himself in 1936" (Smith, 2008).

This brief and rather unusual musical composition, which does not fit into any existing genre of classical music, managed to present a class of its own. In the 1990s, Mikhail Gorbachev, Bill Clinton, and Sophia Loren narrated it for disks.

The purpose of this article was to explore the circumstances of the composer's life during the creation of Peter and the Wolf and at later stages in order to better understand the ending of the tale, which can be viewed as a kind of prophecy expressed in Aesopian language. Questions arising in any source related to Prokofiev (with the exception of the works of music theorists) point to many ambiguous facts in the composer's life that are still awaiting in-depth study. Exploring the phenomena of Soviet literature, music, and theater of the 1930s provides us with important skills for studies of modern (and postmodern) art in different parts of the world. On the other hand, the study of the stories behind the artifacts is, in general, the most promising area of both disciplinary and interdisciplinary research in the field of arts and social sciences today. 


\section{References}

Erlichman, V. (2016). Prokofiev and Russia: One song for two (in Russian). Istoria.RF. Retrieved April 23, 2019 from https:/histrf.ru/biblioteka/b/prokofiev-i-rossiia-odna-piesnia-na-dvoikh

Golitsyna, N. (2013). Lina Llubera, Prokofieva (in Russian). Sovershenno Sekretno. Retrieved April 25, 2019 from https://www.sovsekretno.ru/articles/id/3609

Klyuchnikova, E. (2019). 12 quotes from the diaries of Sergei Prokofiev (in Russian). Arzamas. Retrieved May 2, 2019 from https://arzamas.academy/mag/667-prokofiev

Morrison, S. (2013). Lina and Serge: The love and wars of Lina Prokofiev. Boston: Houghton Mifflin Harcourt.

Norris, G. (2003). My father was naïve. The Telegraph. Retrieved May 2, 2019 from https://www.telegraph.co.uk/culture/music/ classicalmusic/3588909/My-father-was-naive.html

Predota, G. (2016). Lina and the wolf: Sergei Prokofiev and Lina Codina. Interlude. Retrieved May 7, 2019 from https://www.interlude.hk/front/lina-wolf-sergei-prokofiev-lina-codina

Robinson, H. (1987). Sergey Prokofiev: A biography. New York: Viking Penguin.

Sandler, V. (2016). Guilty without guilt: A woman who sacrificed herself in the name of love for her husband (in Russian). Krugozor. Retrieved May 7, 2019 from https://www.krugozormagazine.com/show/prokofiev.2946.html

Smith, T. (2008). Essay: Prokofiev's "Peter \& the Wolf”. PBS (Public Broadcasting Service). Retrieved April 24, 2019 from http://www.pbs.org/wnet/gperf/peter-the-wolf-essay-prokofievs-peter-the-wolf/27

Taruskin, R. (2019). Found in translation. Min-Ad: Israel Studies in Musicology Online, 16, 1-31.

Varyash, A. (2013). Sergey Prokofiev and his two muses (in Russian). 7days.ru, June 20. Retrieved April 25, 2019 from https://7days.ru/caravan/2013/6/sergey-prokofev-i-dve-ego-muzy.htm\#

Vishnevetsky, I. (2011). Prokofiev was not a pure composer (in Russian). Chastnyj Korrespondent. Retrieved April 25, 2019 from

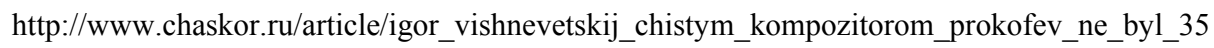

